Márfi A. (1988): Baranya megye egyesületeinek vizsgálata (1915-1950). In: Szita László (szerk) 1988: Baranyai Helytörténetírás 1987-1988. Pécs: Baranya Megyei Levéltár Évkönyve. 251-288.

Márfi A (1989): Baranya vármeove egyesületei (1867-1914) In: Szita László (szerk) 1989: Baranyai Helytörténetírás 1985-1986. Pécs: Baranya Megyei Levéltár Évkönyve. 133-161.

Márfi A. (1989): Pécs szabad királyi város dualizmus kori egyesületeinek vizsgálata. In: Szita László (szerk.) 1989: Baranyai Helytörténetírás. Pécs: Baranya Megyei Levéltár Évkönyve. 193-214.

NÁrAI M. (2003): Civil szervezetek egy kisváros életében. TÉT XVII. évf. 2003/1. 91-115.

SZÁz A. (2003): A kormány civil stratégiája. Esély, 1.pp. 108-116

KSH 2003. évi gyorsjelentés a nonprofit szervezetekröl.
GÁSPÁR GABRIELlA

\section{Női jogok és a leánynévhasználat a XIX. század első felében}

Évekkel ezelött egy kutatás keretében elvégeztem az 1814-1832 közötti időszakban megjelent magyar folyóiratokat megrendelők társadalmi összetételének vizsgálatát. /Gáspár Gabriella, Agroinform 2002./ Tizenkilenc év előfizetői listáit dolgoztam fel szociológiai és történészi módszerekkel. A mintegy négyezer rekord elemzése során az előfizetők rendi, vallási, foglalkozási, szakmai megoszlását, továbbá a lakóhelyet és az előfizetés éveit vizsgáltam.

A teljes olvasóközönség természetesen többszöröse a 3842 előfizetőnek; $k b$. 10-15 ezer személyre tehető azok köre, akiket elértek ezek a folyóiratok. Minden olyan családban, ahol a férfi előfizette valamelyik kiadványt, legalább egy művelt nővel (felesége vagy lánya) számolhatunk, akiknek egyharmada talán a tudományok iránt is mutatott érdeklődést, fele pedig a kultúra iránt általában, így becslés alapján kb. 1- 2 ezer nő kerülhetett az olvasóközönségbe. Ezen nők rendi összetétele valószínűleg hasonló szerkezetü, mint azoké, akiknek nevét és társadalmi állását ismerjük az előfizetői listák alapján. A XIX. század elején megjelenő folyóiratokat önjogon megrendelő nők összetétele nagyjából megfeleltethető a korabeli kulturális elitbe tartozó nők mintájának. Ebben a szemléletben az előfizetők között szereplő 80 nő nem is annyira kevés.

A kutatás során vizsgált három folyóirat közül a Tudományos Gyüjtemény müködött legtovább (1817-1841), s a 25 év alatt a lap eltartotta önmagát. Nem mondható el ez sem a nyolc évig létező a Felső-Magyarországi Minerváról (1825-1832), sem a legkorábban induló, de csak öt évig fennmaradt Erdélyi Múzeumról (18141818) sem. A kutatás során azonban a Tudományos Gyủjteményt is csak 1832-ig -az attfedés éveiben vizsgáltam -, egyrészt, mivel az első reformországgyủlés kezdő éve (1832) kirajzol egy fajta politikai határt, másrészt, mert a 30-as években megváltozott a hazai sajtó természete. Tehát a vizsgált 16 évben a Tudományos Gyủjteménynek 3055 előfizetője volt, a Felső-Magyarországi Minervának 8 év alatt 581, az Erdélyi Múzeumnak pedig az 5 év alatt 595 .

A 81 előfizető nő a következőképpen oszlik meg a három folyóirat között:

Erdélyi Múzeum (1814-1818): 33

Tudományos Gyüjtemény (1817-1832]): 41

Felsö-Magyarországi Minerva (1825-1832): 12 
Az összes női előfizetés (86) közül 7 esetben fordult elő, hogy a hölgyek több folyóiratra is elöfizettek. A saját néven regisztrált nők abszolút értékben többen vannak a Tudományos Gyűjtemény előfizetői között, mint a másik két folyóirat közönségében. A pesti tudományos folyóirat relatív kedveltsége a nők körében azonban csak látszólagos, hiszen a 41 előfizető nő 16 év alatt jött össze, ami átlagos évi megoszlásban alig 3 fő. Ezzel szemben az Erdélyi Múzeumot előfizető hölgyek száma csak 33 az öt év alatt, éves átlagban azonban 6 személyt jelent, ami a kétszerese a pesti folyóirat női közönségének. A Tudományos Gyüjteménynél csak a Felső-Magyarországi Minervát kedvelték kevésbé a nők, amint az kitűnik az éves átlagban alig 2 megrendelőből.

\section{A folyóiratok karaktere és a „női kultúra”}

$\mathrm{Az}$ a tény, hogy a hölgyek inkább preferálták az Erdélyi Múzeumot, mint a Tudományos Gyüjteményt, a két folyóirat karakterével is összefügg. A Tudományos Gyűjitemény elsősorban tudományos lap, s mint ilyen, inkább a férfiaknak íródott, míg az Erdélyi Múzeum az első magyar nyelvű „revue” volt. Az Erdélyi Múzeum szerkesztője, Döbrentei Gábor tudatosan követte azokat a szellemi törekvéseket, melyek a XVIII. század utolsó évtizedeiben létrejött tiszavirág életủ folyóiratokat is jellemezték. Igyekezett összeegyeztetni a különféle törekvéseket; közölt ugyan tudományt is, de a művészetek jóval nagyobb arányban szerepeltek a publikációk sorában. Az irodalom körüli vizsgálódásokra helyezte a hangsúlyt, összekapcsolva ennek elméletét a nemzeti nyelv kiművelésének programjával, amelyben az eredetiség-elv és Kazinczy szépség-eszménye egyaránt teret nyert. /Gáspár Gabriella 1989./ Ezze szemben a Tudományos Gyüjtemény elvszerủen nem közölt szépirodalmat, irodalomelméleti munkákat és kritikákat viszont annál többet. A folyóirat profiljába csak a tudományok tartoztak, a megjelenő tanulmányok nagy része históriai témával foglalkozott, de meglehetősen sok volt az útleírás, geográfiai és statisztikai munka is.

A pesti folyóirat, amikor megindította mellék-lapját, a Szépliteratúrai Ajándékot 1821-ben, helyes piaci szemlélettel éppen a hölgyolvasókat próbálta megnyerni. Ezen törekvésük eredménnyel járt, hiszen számuk megemelkedett. A Szépliteratúrai Ajándék (1828-tól Koszorú) megjelenése első két évében 11 új hölgy előfizetőt vonzott, ami a Tudományos Gyüjtemény teljes olvasóközönsége szempontjából elenyésző, a folyóiratot előfizető összes nőnek azonban $24 \%$-a, ami nem rossz arány. Kétségtelen, hogy a pesti folyóirat népszerüsége a hölgyek körében az irodalmi melléklet megjelenése után közvetlenül megugrott, a hatás azonban nem volt tartós, mivel az előfizető nők száma nem nőtt tovább ilyen mértékben.

A lányok neveltetése elsősorban a nyelvek és a művészetek elsajátítására irányult. A XIX. század elején még az olyan tudós és művelt férfiak, mint Kazinczy Ferenc is feleslegesnek tartották a nők kimüvelését az egzakt tudományokban. , [...]az én Sophie-m nem egyike a mi tudós asszonykáinknak, noha a bécsi klastromban neveltetvén nyolcesztendős kora olta tizenhatodikáig, el lehet képzelni, hogy kultúra nélkül nem maradék.[...] adjunk hálát az egeknek, hogy nékünk mindkettönknek az az asszonyka jutott, aki örömeinkben részt vehet, s azokat nevelheti, de a ragyogás esztelensége nem háborgatja...”-írja „Sophie” c. levélregényében. /Kazinczy Ferenc 1984.267-268 o./ A férfiak tehát nem szorgalmazták leányaik és asszonyaik komolyabb stúdiumokon való részvételét, amiben a hagyományos szerepmegosztáson túlmenően „az új és a régi nőideál összekapcsolódása is megjelent. Az új, romantikus nőideál szerint a nő legyen fogékony a szépre, legyen érzelmes lelkủ, ugyanakkor ékesítse a társasági életet, beszéljen nyelveket, tudjon zenélni és festeni.

A régi magyar nőideál a nagyasszony, aki ha kell, egyedül is megállja a helyét, határozott, parancsoló, valamint szép és jóravaló, hűséges teremtés. A „kardos asszony”, mint ideál a magyar történelem kényszere hatására jött létre, elsősorban a török hódoltság következményeként, amikor is a férj távollétében nem csak a gazdaságot kellett irányítania az asszonynak, hanem adott esetben az udvarházat is védte az ellenséggel szemben és mellesleg a gyermekeit is nevelte. Ez a nőideál a XIX. század elejére már megkopott, annyi azonban megmaradt belőle, hogy olyan leányokat óhajtottak a korabeli urak nevelni, hogy azok szükség esetén özvegyen is tudjanak élni. „Nem adok én gyermekeimnek ragyogó, de használatos nevelést... Az én lányaim úgy neveltessenek, hogy özvegyek tudjanak lenni, ha férjeket a halál hamar elkapná." |Kazinczy Ferenc 1984. 351.o./ A XVI. századi nőideál azonban nem csak eszmény-emlékként maradt fenn a XIX. században is, hanem mint a női jogok által megerősített norma, amiről később bővebben szó esik.

$\mathrm{Az}$ Erdélyi Múzeumban megjelent írások $42 \%$-a volt szépirodalom, míg a Felső-Magyarországi Minervában csak az írások 12\%-a; a Tudományos Gyűjtemény nem közölt szépirodalmat. Nem meglepő tehát, hogy az Erdélyi Múzeum előfizetői között az öt év alatt arányosan kétszer annyi nő van, mint a Tudományos Gyüjtemény 16 éve alatt, és háromszor annyi, mint a Felső-Magyarországi Minerva 8 éve alatt. E gondolatmenet logikája szerint a nők jobban kellett volna, hogy kedveljék a FelsőMagyarországi Minervát, hiszen jóval több szépirodalmat közölt, mint a Tudományos Gyüjtemény, amely elvszerüen semmit (kivéve az 1821-től megjelentetett a mellékletet, a Szépliteratúrai Ajándékot). Márpedig arányában jóval több nő fizette elő a pest folyóiratot, mint a kassait. Nyilvánvaló, hogy a nők nem csak a publikált szépirodalom mennyisége szerint választották ki a folyóiratot, még ha a korabeli férfiak szerették volna is ezt hinni, hanem a minőség is szerepet játszott választásukban, továbbá a tudományoktól sem iszonyodtak. A Felső-Magyarországi Minerva bár közölt szépirodalmat, ez azonban nem a legfrissebb, és éppenséggel nem is a legjobb minőségü irodalom volt.

A személyes érdeklődés és ízlés mellett komoly szerepet játszott az elő́fizetésekben a mecénási szándék és a nemzeti kultúrához való viszony. A két intenció természetesen összekapcsolódik, hiszen a mecenatúra szándéka karöltve járt a nemzeti öntudattal, de a lokálpatriotizmussal is. Kedves lehet egy lap azért, mert a nemzeti tudat megjelenítője, de azért is, mert szűkebb pátriánkban jelent meg. Ahhoz, hogy ezt a kérdést mélyebben megértsük, előbb az előfizető nők társadalmi helyzetét kell megvizsgálnunk a megrendelői listák által nyújtott lehetőségek függvényében. 


\section{Az előfizető nők társadalmi helyzete és lakóhelye}

Az előfizető nők esetében jóval kevesebb változót vehetünk figyelembe, mint a férfiak esetében. A nőknek nem volt katonai rangja, egyházi tisztsége, szakképzettsége, udvari címe és foglalkozása is csak elvétve. A nők esetében vizsgálhatjuk rendi helyzetüket (ami férjük rendi helyzetét követi); udvari címük csak az udvarhölgyeknek, csillagkeresztes dámáknak volt, mintánkban belőlük csak három található. Vizsgálhatjuk továbbá a foglalkozást, ez azonban csak három asszonynál kimutatható: mindhárman özvegyek, és férjük könyvkereskedő vagy lapkiadó vállalkozását vitték tovább, különösebb képzettség nélkül, özvegyi jogon. A férfiakéval összevethető további elemzési lehetőségeink a 80 előfizető nő tekintetében gyakorlatilag a lakóhelyre, az előfizetett folyóiratokra és az előfizetés éveire korlátozódnak. Van azonban két változó, amely a férfiak esetében nem vizsgálható, a nőknél azonban igen, sőt, további érdekes következtetésekre nyújthat alapot: ez a családi állapot és a névhasználat. Utóbbira a tanulmány végén kerül majd sor, addig is nézzük az egyes folyóiratok előfizetői körét és a lakóhely összefüggését, majd a rendi helyzetet és az előforduló foglalkozásokat.

Lakóhely vonatkozásában a mintában szereplő 80 nő közül 29 személyről semmit sem tudunk, ők a Tudományos Gyüjtemény és a Felső-Magyarországi Minerva előfizetői közül kerülnek ki. A mintában előforduló nők többsége Erdélyben lakott, a leggyakrabban előforduló települések, Kolozsvár (13) és Pest (9). Az Erdélyi Múzeumot megrendelő nők mindegyike közlölte lakóhelyét. Közöttük csupán két pestit találunk a többiek Erdélyben laktak, legtöbben Kolozsvárott. Ennek a folyóiratnak a megrendelői szinte egyöntetủen erdélyi hölgyek voltak, akiket a lokálpatriotizmus legalább annyira mozgatott, mint a nemzeti érzés. A Tudományos Gyűjtemény előfizetői lakóhelyei között a leggyakrabban előforduló település Pest (7fő), azt követi Debrecen és Kolozsvár (2-2 fő). A Felső-Magyarországi Minervát előfizető hölgyek lakóhelyét csak 4 esetben ismerjük, ezek között semmilyen ismétlődés nem figyelhető meg.

A XIX. század eleji magyarul olvasó női közönség rendi megoszlása a következő képpen alakult: 40 főnemes (ezen belül 30 gróf, 10 báró), 30 köznemes, 10 polgár. Tehát a 80 előfizető nő fele (50\%) fönemes, közülük 28 lakott Erdélyben és csupán 2 fő Magyarországon, 1 személy Bécsben, 11 főrendű nőnek pedig nem ismerjük a lakóhelyét. A főnemesek körében valószínűbb a fentebb felvetett mecénási szándék megjelenése az előfizetésben. A legtöbb főrendű asszony az Erdélyi Múzeum előfizetői között található, szám szerint 23, a lapot előfizető nők mintegy 70\%-a. A többi két lap esetén nem ilyen magas a főrendű asszonyok száma, a Tudományos Gyűjtemény közönségében csak 12 fő, a Felső-Magyarországi Minervánál pedig 10 fő. A XVIII. század végétől folyamatosan erősödỏ magyar nemzeti öntudat, és az ezt kifejező nyelviség bölcsője is Erdély, elég, ha az Aranka György által szervezett nyelvművelő társaságra gondolunk, amely a Magyar Tudományos Akadémia első kezdeménye volt. Erdélyben nem veszett ki a magyar nyelv használata azokban az időkben sem, amikor Magyarországon alig találunk olyan főúri asszonyt, aki beszélne magyarul. Kazinczy írta magyarországi barátainak (Berzsenyinek és Kis Jánosnak), hogy amikor Erdélyben járt, nem talált „dámát” (ahogy férfit se), akivel németül kellett volna beszélnie, s nem magyarul. Azért volt ennek különös jelentősége, mert Magyarországon a század első évtizedeiben az úrhölgyekkel nem lehetett magyarul beszélni, minél magasabb volt a társadalmi státusa annál inkább úgy kellett tanulnia a magyar nyelvet, mint az idegen nyelveket. Az erdélyi asszonyok viszont nemzeti kötelességüknek tartották a magyar nyelv és kultúra támogatását, de értését és művelését is.

A Felső-Magyarországi Minervát előfizető viszonylag kevés, javarészt főrendű hölgy nagyrészt azonos a Tudományos Gyüjteményt előfizető dámákkal; esetükben a mecenatúra elsődleges szándéka nyilvánvaló. A Tudományos Gyűjtemény előfizető hölgyei között a köznemes- és polgárasszonyok vannak többségben. A pesti lapot 12 lơrendű, 19 köznemes és 10 polgárnő fizette elő. Közönségében a köznemesek és polgárnők együttes aránya 70\%, tehát a „legpolgáribb” folyóiratnak mondható a három közül.

A három folyóiratot előfizető 28 köznemes nő közül csak 17-nek ismerjük a lakóhelyét. Öten közülük Erdélyben laktak, két-két személy Pesten és Sopronkálon, lovábbá egy-egy fő Szathmár és Bereg megyében. A polgárnök közül 4-nek nem ismerjük a lakóhelyét, három Pesten, egy-egy személy pedig Debrecenben, Bártfán, Kápolnásnyéken lakott. A polgárasszonyok közül hárman könyvkereskedők özvegyei, akik férjük vállalkozását vitték tovább.

Özvegy Csáthy Györgyné és örökösei Debrecenből együtt rendelték meg a Tudományos Gyűjteményt 1831-32-ig. A férje - aki a lap indulásától szerepelt az clőfizetők között - halála után lépett be az asszony a megrendelök közé. Csáthy Görgy debreceni könyvkereskedő volt, $\mathrm{s}$ az asszony az ő helyére állva, fiai gyámjaként vette at és folytatta az üzletet gyermekei nagykorúságáig. A következő könyvkereskedő özvegy Kiss Istvánné, aki József fiával együtt rendelte meg a Tudományos Gyűjteményt az első három évben. A későbbiekben nem találjuk az előfizetők között, valószínűleg fia, nagykorúvá válván, saját jogon belépett a megrendelők közé. Özvegy Kultsár Istvánné férje halála után folytatva a vállalkozást jelent meg az előfizetők között. Kultsár István a Hazai Tudósítások kiadója és tulajdonosa volt, korának jeles irodalom pártolója, aki nem csak lapot szerkesztett, de irodalmi szalont is tartott fenn Pesten. Kultsár halálával szalonja is megszűnt, özvegye a vállalkozást tovább vitte, a szalont azonban nem lett volna sem illendő, sem lehetséges, hiszen ez utóbbi férje személyes ismeretségein és baráti társaságán alapult. Özvegye magát, mint laptulajdonost prezentálta, feltehetően fiú utóda nem volt, különben Csáthynéhoz hasonlóan az örökösöket is feltüntette volna a megrendeléskor.

A magyar nők joga volt, hogy megözvegyülésük esetén férjük vállalkozását tovább vigyék, birtokait kezeljék és húzzák hasznait halálukig, ha nincs fiúgyermekük, ha pedig van, annak nagykorúságáig. A korábbi századokban is így volt ez, a peres iratokból tudjuk, hogy a XVI. századtól az özvegy nemesasszonyok birtokaik, a jobbágy ozvegyasszonyok pedig telkeik ügyében önállóan jártak el. /Péter Katalin 2001. 23.o./ A különböző társadalmi állapotok esetén a jogi helyzet hasonló; férjük halála után az asszonyok „özvegyi jogon” jártak el a haszonvételek tekintetében, a leendő örökösök vonatkozásában pedig gyámként. Ha nem volt gyermekük, a jobbágyasszonyok akár örökölhették is a gazdaságot illetve a közszerzeményi telket, az úrbérest azon- 

kik járt. A női jogok áttekintése mindenképpen szükséges annak eldöntéséhez, hogy vajon a nők valóban alávetettek voltak-e a tradicionális társadalmakban, $\mathrm{s}$ ha igen, milyen módon és milyen racionalitás alapján.

\section{Női jogok a magyar rendi társadalomban}

A magyar asszonyok számos olyan személyi, családi és közéleti joggal rendelkeztek, amelyek Európa más országaiban nem voltak szokásosak, vagy jóval kevésbé voltak kiterjedtek. Tárgyunk szempontjából elsősorban a Werbőczy Tripartitumában leírt szokásjognak van jelentősége, továbbá a XIX. század elejéig tartó jogalkotás egy-két elemének.

A nők személyi jogainak egyik legalapvetőbb korlátozása volt a nemi gyámság intézménye (tutelle du sex), amely a középkorban mindenütt jellemző volt, s azt jelenttette, hogy a nők egész életükön át kiskorúak maradtak, állandóan egy férfi (a családapa, vagy a férj) gyámságának voltak alávetve. Magyarországon is fennállt a nemi gyámság, azonban igen korlátozott volt. Nálunk csak a hajadonok voltak a nemi gyámságnak alávetve, férjezett, özvegy vagy elvált asszonyokra nem terjedt ki.' A nemi gyámságnak alávetett leányok sem voltak cselekvésképtelenek, 12 éves korukban törvényes korúak lettek, már ügyvédet tarthattak, míg a fiúknak csak 14 éves koruktól nyílt meg ez a lehetőségük. A nők már 14 éves korukban intézkedhettek zálogos javaikról és ingóságaikról, 16 éves korukban pedig nagy korúak lettek, amikortól teljes vagyonukkal és jogaikkal rendelkezhettek, ezzel szemben a férfiak csak 24 éves korukban érték el a teljes korúságot. Meg kell említeni a személyi jogok között a vérdíj (homagium) középkori intézményét, amely az a váltságdíj, amit a gyilkos a megölt személy családjának köteles fizetni. Más európai jogrendszerekben a nők vérdíja gyakran alacsonyabb volt a férfiakénál, nemritkán a fele (pl. német területeken), míg nálunk a férfi és a nő vérdíja között különbséget nem tettek.

A magyar személyiségi jognak női szempontból fontos intézkedése volt a fiúsítás (praefectio) intézménye. A fiúsitás, vagy „fiúággá való tétel” /Máday 191328 o./ lényege az volt, hogy ha egy nemesembernek nem volt fiú csak leány gyermeke, akkor a király kedves, hủ emberének lányát megfiúsíthatta. Ilyenkor a leány a fiújogok örököse lett, örökölhette az ősi foglalású vagy nemzetségi birtokot, amit egyébként a lányok nem örökölhettek.

Leány csak az apja vagy a férje által végrendeletileg ráhagyott szerzett birokot örökölhetett, illetve olyan adománybirtokot, aminek vonatkozásában az adományozónak nem volt semmilyen konkrét kikötése. Nemzetségi birtokot a leányutód nem azért nem örökölhetett, mert alacsonyabb rendű volt a fiúknál, hanem egyszerủen azért, mert házasodása esetén a nemzetségi birtokrészt kivitte volna a nemzetségből. Márpedig a nemzetségi vagy ősi foglalású birtokok tekintetében a tulajdonjog három eleme (usus, possessio, potestas) közül a rendelkezési jog a nemzetségé. A magyar nemesség a birtoköröklésben a fiú utódok egyenlőségét vallotta, ennél fogva gyakorta

öfordult, hogy a nemzetség egyik-másik ága elszegényedett a birtokok aprózódása miatt. A magyar nemességnek elemi érdeke volt számon tartani a nemzetségi rokonságot, hiszen az egyik ág magvaszakadása esetén az „osztályos atyafiak” (frater condivisionalis) közül a másik ágra szállt a kihalt ág birtoka. /Fügedi 1992. 10.o./

Az öröklés fiágon történt, a nők mentek a férjük nemzetségéhez, érthetỏ tehát, hogy a lányok csak kivételes esetben örököltek olyan birtokrészt, ami végső soron a nemzetséghez tartozott. Az egyik kivételes eset a fiúsítás volt, a másik, ha a leány nem nemeshez ment férjhez. Ebben az esetben örökölt a nemzetiségi birtokból, ami azért volt ésszerű, mert ebben az esetben a nő nem vitte át a birtokrészt a férje klánjába, hiszen az nem tartozott nemesi nemzetséghez. Ha a leány ebben az esetben nem örökölt volna ősiségi birtokrészt, akkor az utód birtok nélkül kiesett volna a nemességből, így viszont az anyai birtokot örökölte ő és leszármazottai. Félnemesnek (agilis) hívták, akinek csupán az anyja volt nemes, ezeknek a leszármazottaknak a társadalmi státusa gyakorlatilag az anya családjának a presztizsétől függött, hogy mennyire voltak képesek elfogadtatni a nem-nemes vőt és leszármazottját a megyei nemesi gyủlés előtt.

A király által végzett fiúsítástól (praefectio regiae) különbözött a fiúlányság (praefectio naturalis), amely Erdélyben volt szokásos. Ott a nőknek több joga volt, mint Magyarországon: nem kellett a király beleegyezése a fiúsításhoz, fiú utód hiján a lány egyszerüen beöltözött fiúnak és a birtok örökébe lépett. A fiúsítás következtében a birtok a nő ágán öröklődött tovább.

A nők cselekvőképessége több vonatkozásban meghaladta a férfiakét, ami korai nagykorúvá válásukkal is összefüggött, pl. már 16 éves korukban folyamodhattak iparüzleti engedélyért, míg a férfiak csak 20 évesen. 1840-től már a nők korlátozott váltóképességét is elismerte a törvény, ${ }^{2}$ váltót azok az asszonyok és hajadonok írhattak alá, akik törvényesen bejegyzett céggel rendelkeztek.

A házassági jog tekintetében már az Árpád-ház uralmának időszaka alatt utat tört a férjes nők önjogúságának elve. Egyrészt a férj sem köteles felesége bủneiért jótállni, de a feleség sem férje bűneiért. ${ }^{3}$ A magyar asszonyok önjogúságát bizonyítja, hogy a férjes nő nem áll nemi gyámság alatt, a férjének nincs felette „férji hatalma”, továbbá a férjnek házi fegyelmi joga sincsen a felesége felett. Törvényeink ezt expressis verbis nem mondták ki, viszont a törvényes joggyakorlat szentesítette az önjogúságot. Jogtudósaink egybehangzóan állítják, hogy a törvény hallgatása ez esetben a férji hatalom nemlétezését jelenti. ${ }^{4}$

„Nálunk...férji hatalom nincs, soha nem is ismerte azt sem a törvény, sem a szokás." |Kolozsvári 1899. 40.o./ Az 1807. évi VIII. tc., amely a perrendtartáśól szól, taxatíve felsorolja azokat, akik a perbe idézett felek törvényes alárendeltjeinek tekinthetők, ezek között pedig feleség nem szerepel. A férj családfői hatalma a nő cselekvési körét csak a lakóhely szabad megválasztásában korlátozza, ugyanis a család lakóhelyét a férj határozza meg és a nő követni köteles. De még ezt sem feltétlenül - Cserei szerint -, mert ha már a házasságkötés előtt megállapodtak abban, hogy hol fognak lakni, a feleség később nem köteles egy másik, a megállapodástól eltérő lakóhelyre követni a férjét. A nő a férjétől független jogalany, a férj a feleségét, sem perben, sem azon kívül nem képviselhette meghatalmazás nélkül. 

azonban a nőt egyszerűen csak visszavezették férjéhez, addig a férfi elveszítette vagyonát és újranősülési jogát. Amíg a nő férjét várni kívánta, annak összes vagyonát bírta, de ha újra férjhez akart menni, azt is megtehette, a férj ellenben csak püspöki engedéllyel nősülhetett újra. /Máday im 45 o./

Az asszonyoknak a házasságban voltak olyan jogaik, amelyek egyoldalúan csak a nőket illették meg; viselhették férjük nevét és rangját, ha nemnemes nő nemeshez ment férjhez, szintén nemességet nyert („közlött nemesség”). A férj nevének viselése inkább jog, mint kötelesség, hiszen a nők leánynevéhez való jogát az évszázados gyakorlat szentesítette. A nők lánynevükhöz való öntudatos ragaszkodása a XIX. században különösen gyakori volt.

Az asszonyokat megillette a tartásjog, ami azt jelenti, hogy a férj köteles vagyoni és társadalmi állásához képest eltartani, lakásról, ruházatról és élelemről gondoskodni számára. Mindezt a férj vagyonából kellett finanszírozni, nem követelhette a nőtől, hogy saját vagyonából ehhez hozzájáruljon.

A magyar nő, személyi és házastársi jogai tekintetében a férfiakkal úgyszólván egyenjogú volt, a szülöi jogok tekintetében azonban, csaknem jogtalan volt a rendi társadalomban. Mindez a régi patriarchális jogrend maradványa, ami alól a feleséget lassanként emancipálták a törvények, a gyermekeket azonban nem. A nők már jóval a Hármaskönyv létrejötte előtt felszabadultak a férji hatalom alól, a gyermekek azonban nem. Ennek maradványa a lányokra vonatkozó nemi gyámság is, hiszen a fiúgyermekek ugyanannyira az atyai hatalom alá tartoztak, mint a lányok, sôt a törvényes kort is késỏbb érték el. A házastársat a fiúk számára is az atyjuk választotta ki - ahogy a lányok számára is -, ugyanannyira kötelező erővel. A szülői hatalom sokáig kizárólag atyai hatalom volt, s csak a XVIII. században ${ }^{5}$ jelent meg a „szülői hatalom” (parentalis potestas) kifejezés, amelybe már az anyát is beleértették. Itt nem az atyai hatalom anyával való megosztására gondol a törvény, hanem arra, hogy az atya hiányzik vagy cselekvőképtelen, az anya helyettesíti az atyai hatalmat.

Az özvegy még a férjes asszonynál is szélesebb cselekvőképességgel rendelkezett a régi magyar jogban, majdnem minden téren - részben még politikai tekintetben is - egyenrangú volt a férfival. Sőt, bizonyos értelemben a jog még a férfitársadalom ellen is védelmezte őt és gyermekeit. Az ura halála évében az özvegyet senki perbe nem idézhette, még az uráról rámaradt perbe sem, ezen idő alatt férje vagyonából kirekeszthető nem volt. A XVI. században az egytelkes nemesek a telek után fejenként mentek hadba, ellenben özvegyeik - ha nem volt hadra fogható fiúk, - csak imádkozni voltak kötelesek. ${ }^{6}$ Mindezek a kiváltságok a rendi alkotmány eltörlése után eltűntek.

A magyar rendi társadalomban a női házassági vagyonjogok viszonylag korán kialakultak. A női különvagyonnak az első nyomait a leány negyed intézménye körül találjuk meg. Árpádkori iratok szerint a nők a királytól, családjuktól, férjüktől kaptak birtokot, amely fölött a házasság alatt is rendelkeztek, eladhatták, elajándékozhatták. Werbőczy Hármas könyvében szintén kitért arra, hogy a férj és feleség egyaránt sza-

badon rendelkeznek „minden, kivalt a maga által szerzett vagy másképp nyert birtok jogai iránt" / Werböczy 110\$./ A nó különvagyonához tartozott az a tulajdon, amivel a házasságkötéskor bírt, és amihez a házasság tartama alatt ingyenes módon (örökség, ajándékozás) jutott.

A jegyajándék hajdan a nő különvagyonának speciális formája volt, elsősorban ingóságokat (ruhanemű, ékszer, háztartási eszközök) tartalmazott, amelyeket a nő a férjétől, annak rokonaitól, illetve szüleitől kapott az eljegyzés vagy a házasságkötés alkalmából. A jegyajándék a korai időkben még önkéntes szokásokon alapuló hagyomány, volt Werbőczy azonban már „köteles részként” értelmezte, ami a férjhez menő lánynak járt atyjától, annak halála esetén pedig a fiútestvérektől. 1800-ban megjelent könyvében Cserei már kötelező jellegét domborítja ki azzal, hogy mértéke egyezzen meg a leány díjával, a homagiummal /Cserei 1800. 135 o./. Amennyiben a jegyajándékra nem volt elég pénze az atyának, úgy ingatlanjai jövedelmét kellett erre a célra fordítania.

A hozomány különbözött a jegyajándéktól: a feleség tulajdonában állt, azonban férjének haszonélvezetre, kezelésre átadta, s a házassággal járó kiadások fedezésére szolgált. A hozomány a régi jog szerint eredetileg csak ingóság lehetett, később azonban ingó és ingatlan vagyon egyaránt. A hozomány jellemzője, hogy a férj haszonélvezetéből elvonni nem lehetett a házasság fennállása alatt. A házasság felbomlása, halál vagy válás esetén a hozományt köteles a férj vagy örököse feltétel nélkül kiszolgáltatni, sőt az özvegy férje javait mindaddig visszatarthatja, amíg az örökösök hozományát ki nem szolgáltatják.

A hitbér az egyik legrégebbi magyar jogintézmény, amelyet a férj adott feleségének házastársi kötelezettségei teljesítése ellenértékeként. ${ }^{7}$ Kezdetben ingóságok ból állott, később ingatlan is lehetett. Az Aranybulla 12. cikkelye foglalkozott már vele, s kimondta, hogy az elesett vagy halálra ítélt férfiak feleségeit hitbérüktől megfosztani nem lehet. A hitbér összege a férj rendi állásához igazodott és megegyezett a vérdíj összegével. ${ }^{8}$ Hitbért adni kötelező, de csak a törvényesen köttetett és elhált házasságokban. Az első házasság a hitbér teljes összegére, a második csak a felére, a harmadik házasság az egynegyedére jogosított. A hitbér kifizetése akkor volt esedékes, amikor a házasság valamilyen okból felbomlott, lehetett az haláleset vagy válás. Ha a férj halt meg, az özvegy örökösödési joga a hitbérre mindenképpen kiterjedt, a feleség halála esetén pedig mindenkori örökösét illette meg. A válás csak akkor nem jogosított a hitbérre, ha a nő hibájából következett be. A hitbérnek két fajtája volt, az eddig ismertetett törvényes, és az írott hitbér, amely megállapodás kérdése, lehetett több is meg kevesebb is a törvényes hitbérnél. Természetesen az írott hitbér kizárta a törvényes hitbérre irányuló jogot, viszont válás esetén is feltétlenül követelhető volt.

A közszerzemény a házassági vagyonjog egyik későbbi, a XV. század körül keletkezett intézménye, azonban csak a nem-nemesekre vonatkozott. A közszerzemény az a vagyon, amit a házastársak a házasság alatt szereztek, de nem tartozott egyikük külön vagyonába sem, azaz meghaladta a házasság előtt megvolt és a külön vagyon összegét. A házasság felbomlása után két részre osztatott a férj és a feleség, illetve jogutódaik között. A férj halála esetén az özvegy nem mint örökös léphet fel, hanem mint tulajdonos kapta kézhez a közszerzemény ráeső részét, hasonlóan a hozomány- 

visszaállítását rendelte el, szintén elismeri, hogy a magvaszakadt javai nemzetsége mindkét nembeli tagjaira szállnak, s nem kerülnek kihirdetésre. /Bónis 1942. 71-72.o./ Tehát a székely jog sajátsága, hogy az ősi székely birtokban, a ,székely örökségben” a lányokat is részesíti. A székely ősi birtok a magyar ősi foglalású vagy nemzetségi birtokhoz hasonló birtok típus, ennél fogva fokozott védelem illette meg. Nem lehetett elzálogosítani, sem eladni, mivel végső tulajdonosa a nemzetség, a rendelkezési jog a közösséget illette meg. Alapvető szabály volt a székely öröklésben a fiág elsőbbsége, kivéve a pénzen szerzett birtokot, mert ebben a lányok a fiúkkal egyenlően örököltek. Az ősi székely birtokot elsősorban a fiúk örökölték, a lányok öröklése csak ezek híján állt be. Ha egyáltalán nem volt örökös, sem más leszármazott, akkor az oldalág örökölt, ahol a nővér, leánytestvér öröklése is megnyílhatott, vagy az ő leszármazottaié, akik közül előbb a fiúk, majd a lányok örököltek. / Cserei im. 80.o./Érdekes az atyai és anyai javak bizonyos értelemben vett külön kezelése, ami a kiházasítás és az öröklés összefüggésében látszik meg, ti. ha a lányt - akinek ugyanúgy joga volt a kiházasításra, mint a magyar lányoknak -, az anyai javakból házasítják ki, akkor az atyai javakból a férfiakkal egyenlően osztozik: Ha a kiházasításuk elmaradt, akkor is egyenlően örököltek a fiúkkal. A fiúlányság nem csak a leány utódot illette meg, de az örökhagyó nővérét, annak hiányában pedig távolabbi örököseit is. ${ }^{13}$

Nem tudjuk, hogy a fiúlányt székely örökségként megilletỏ birtok a férje kezelése alá került-e egyáltalán, feltehető azonban, hogy megkülönböztették a férj és a felesége vagyonát. Azonban a férjet is megillette a felesége után az öröklési jog, legalábbis akkor, ha nem voltak osztályos rokonok. A fiúlány férje gyakran felvette a felesége nevét és gyermekeik is az anya nevét viselték. ${ }^{14}$

Talán ezzel a székely leányfiúságból fakadó gyakorlattal is összefügg az a körülmény, hogy az erdélyi férjezett nők gyakrabban használták leánynevüket, mint a magyarországi részeken lakó asszonyok. Az alábbiakban, a dolgozat elején írottakhoz híven megvizsgáljuk a három folyóirat előfizetői hölgyeinek névhasználatát.

A XIX. század elején múködő három folyóiratot megrendelő 80 nő névhasználatának vizsgálata során először családi állapot szerint elkülönítettem a hajadonokat, a férjezett asszonyokat és az özvegyeket. A mintában mindössze 10 hajadont találtam, rendi helyzetük szerint 5 kisasszony fönemes, 5 pedig köznemesi származású, közöttük nem található polgárleány. A század elején a magyar kultúra iránt értelemszerủen a nemes hölgyek tanúsítottak nagyobb érdeklődést, már csak azért is, mert a korban megkívánt műveltség számukra elérhetőbb volt, mint a polgárleányok számára, hiszen - mint ismeretes - megfelelỏ iskolák híján a nemesek leányai legalább házi nevelésben részesültek. A hajadonok közül heten Erdélyben laktak, egy személy Pesten, egy a felvidéken, egy pedig Sopron mellett. A leányok közül nyolc személy fizette elő az Erdélyi Múzeumot, egy-egy pedig a Tudományos Gyüjteményt és a Felső-Magyarországi Minervát. Az erdélyi kisasszonyok voltak tehát többségben, akiknek érdeklődése érthetően inkább szűkebb pátriájuk folyóirata felé fordult.

Az elófizetó nők között 70 asszony található, társadalmi helyzetük vizsgálatát elvégezhetjük a rendi helyzet, a családi állapot és a lakóhely, illetve a folyóiratok választása szempontjából. Rendi helyzetük alapján 35 fỏnemes, 25 köznemes és 10 polgári származású asszony van a mintában. Az asszonyok fele fỏnemes, ahogy a hajadonok között is, míg azonban a hajadonok között nincs polgári származású, addig az asszonyok között 14\%-os a polgárnők aránya. A 70 asszonyból 44 fő férjezett, 26 nő pedig özvegy. A férjes asszonyok csoportjában (44 fö) a rendi helyzet a következőképpen oszlik meg: főnemes 22 , köznemes 17 , polgár 5 asszonyszemély. Összehasonlítva ezt az özvegyek rendi helyzet szerinti megoszlásával: főnemes 13 , köznemes 8 , polgár 5 , azt látjuk, hogy a fỏnemes nők arány azonos a házas és az özvegy kategóriában, azaz mindkét csoportnak a fele. A köznemes asszonyok esetében már mintegy 8-9\%-os különbség mutatkozik a házas nők javára, a férjes asszonyok 38,6\%-a köznemes, míg az özvegyeknek csak a 30\%-a. A polgárasszonyok mintegy kétharmada özvegy, s csak egyharmada férjezett. Az özvegyek úgy tủnik, bátrabban jelentek meg saját jogon, társadalmi állástól függetlenül, mint a férjes asszonyok. Mindez bizonyítja, hogy a magyar történeti női jogok közül az özvegyi jog volt a legjelentősebb társadalmi szinten. Minél alacsonyabb volt a státusa a nỏnek, annál inkább csak akkor prezentálta magát önjogon, ha megözvegyült. A magas társadalmi státusú hölgyeknek nem volt szükségük öntudatuk megerősítéséhez az özvegyi jogokra.

Az asszonyok névhasználatára azért érdemes kitérni, mert a leánynéven való nyilvános megjelenés mögött meghúzódott egy sajátos, a történelemben és a jogban gyökerező öntudat, amely - feltételezésem szerint - különösen az erdélyi nőknél jelentkezett. A névhasználat vizsgálata természetesen csak a 70 asszonyra terjedt ki, megkülönböztetve a leánynevüket, az asszonynevüket, illetve a férjük nevét vezetéknévként viselő személyeket. Leánynevét használja az előfizetői listák tanúsága szerint 44, asszonynevét 18, asszonynevét félig, csak vezetéknévként további 8 nő.

A férjes asszonyok és az özvegyek csoportját a névhasználat szempontjából is érdemes külön megvizsgálni. Az özvegyek közül 18 nő viselte leánynevét és csak 8 személy az asszonynevét, míg a házasságban élő asszonyok közül 26 leánynéven jegyezte magát és 18 asszonynevén. Az özvegyek nagyobb arányban viselték lánynevüket, mint a férjes asszonyok, továbbá Erdélyben lakott az özvegyek több, mint fele, s közülük csupán egy viselte a férje vezetéknevét. Azon özvegyek közül, akik Magyarországon laktak (12 fő), csak a nemes asszonyok viselték leánynevüket (egy személy kivételével), a polgárasszonyok pedig egyértelmủen hangsúlyozták a férjük utáni jogfolytonosságot. A házasságban élő, de lánynéven szereplő asszonyok fele-fele arányban éltek Erdélyben illetve Magyarországon. Az Erdélyben lakó nők között majdnem teljes körủ a leánynév használata. A XIX. század elején a magyar olvasóközönség körébe tartozó nők közül 51 személynek ismert a lakóhelye, közülük 35 lakott Erdélyben, s e csoportból 31 asszony viselte a leánynevét.

Ha a családi állapot, a névhasználat és a lakóhely mutatóit összekapcsoljuk, látható, hogy elsősorban az erdélyi nők, arányaikat tekintve elsősorban az özvegyek használták leánynevüket, amiből arra következtethetünk: ez a legönállóbb, legöntudatosabb női csoport. Ez az öntudat a történeti nỏi jogokon, elsősorban az özvegyi 
jogon, továbbá a székely jog nökre vonatkozó kedvezményein alapult. A székely gyakorlat arra inspirálta az erdélyi asszonyokat, hogy leánynevüket megtartsák, azt önállóan vagy férjük nevével együtt használják.

\section{Jegyzetek}

A nemi gyámságot az 1874.évi XXIII. tc. törölte e

1840.évi XV. tc.

Szt. István II. törvénykönyve 29. fejezet, Szt. László II. tvk. 12 fej. és III. tvk. 6. fej. , Kálmán I. tvk. 56. fej Jancsó, Fodor, Szlemenics, Tóth, Katona, Kolozsváry stb. vö. Máday im. 37. o.

1723. évi CXI. tc.

Vö. 1545.évi XXI. tcx.

A jogtörténészek szerint a magyaroknál a hitbér a leány vételárából fejlődött ki - hasonlóan Európa más országainak jogfejlődéséhez - ahogy, a jegyajándék és a jegygyűrủ pedig a vásár megkötésekor fizetett „felpénzbỏl”(ma foglaló hasonlítható hozzá) alakult ki. Máday im. 85-90 o.

A Tripartitum 93. cikkelyének 4. §.-a felsorolja az egyes rendek hitbérének fix összegeit, főnemeseké 100 márka, köznemeseké és polgároké 50-50 márka. A 6.-8. \$-ból azt is megtudhatjuk, hogy 100 márka akkor egy kőből épült vár értékének, 50 márka pedig egy két tornyú templom értékének felel meg.

A magyar házassági vagyonjog a közszerzeményi rendszernek felel meg, s mint ilyen a nöknek kedvezö vagyonjogi rendszerek csoportjába tartozik. A különbözỏ rendszerek három jogi alapelvre - vagyonközössé kezelési közösség vagyon elkülönítés- és ezek különböző kombinációira vezethetök vissza. Máday im.66-71 kezer

o.

A nemesekre egyetlen esetben vonatkozott a közszerzemény, amikor a nemes embernek „feleségével való házassága alatt gyüjtött vagy vett ménes lovai ötvenen alul vannak egyenlően fognak köztük elosztatni..,” Werbőczy I. 101.c.

Az 1.§. ideiglenesen fenntartja azon nők választójogát, akik azt addig is gyakorolták.

Bónis György Cserei Farkashoz hasonlóan mind a nővér, mind a lány utódok fiúlányságát fogadja el, szemben Vargyasi Szolga Jánossal, aki csak a nővér fiúlányságára következtet. Vö. : Bónis im. 75.-86. o., Szolga im. 238, 245, o.

Vö:: 1674-ben Apor Ilona fuúlány törvényes gyermekei Apor István, László és Mihály Bónis im. 88. o

\section{Felhasznált irodalom}

Bónis György: Magyar jog-székely jog, Kolozsvár 1942. Ferenc József Tudományegyetem

Cserei Farkas: A magyar és székely asszonyok törvénye, Kolozsvár 1800.

Csíky Kálmán: A magyar nők jogai, Budapest 1894.

Gáspár Gabriella: A polgári nyilvánosság kezdetei Magyarországon, Bp. Agroinform 2002

Gáspár Gabriella: Die Stelle der Zeitschrift „Erdélyi Múzeum”(1814-1818) in unserer Wissenschaftsgeschichte In.: Specimina Nova, JPTE Történelem Tanszékének Évkönyve, Pécs, 1989 29-46 p.

Fábry Anna: Író nők vagy írónők? A női dilettantizmus és professzionalizmus kérdése a 19. századi magyar irodalomban $=$ Rubicon 2001/6. 25-29 o.

Fügedi Erik: Az Elefánthyak, Bp. 1992. Magvetô kiadó

Kazinczy Ferenc: Sophie, Bp.1984. Szépirodalmi kiadó

Kolozsváry Bálint: A közszerzemény biztosítása, Budapest, 1899.

Kempelen Béla: Magyar nemes családok 10 k.+ pótkötet, Bp. 1911-1932. Grill k.

Máday Andor: A magyar nö jogai a múltban és jelenben, Atheneum irod. és nyomdai Rt. 1913.

Nagy Irán: Magyarország családai czímerekkel és nemzékrendi táblákkal 1-12 k.+ pótkötet, Pest 1857-1868. Freibeisz István és Táth Mór $k$.

Péter Katalin: Nők önállósága, férfiak önállósága a társadalomban= Rubicon 2001/6. 20-24 o.

Székely (killényi ) Mihály: A nemes székely nemzetnek constitutiói, privilégiumai és a jószág leszállását tárgyazó nénely törvényes ítéletei, több hiteles leveles-tárakból egybeszedve, Pest 1818 . Trattner $k$.

Szolga (vargyasi) János: Székely jogi ötven kérdések s 102 feleletek, Marosvásárhely, 1844. Ref.koll.

Takáts Sándor: Régi magyar nagyasszonyok, Szépirodalmi könyvkiadó Bp.1982

Tárkány Szűcs Ernő: Mártély népi jogélete, Kolozsvár 1944. Kolozsvári Egyetem Jogtörténeti szeminárium

Tárkány Szücs Ernő: Magyar jogi népszokások, Bp. 1980. Gondolat k.

Tóth Zoltán: A rendi norma és a „,keresztyén polgáriasodás” = Századvég 1991. 2-3. sz. 75-130 o. 